\title{
Can a deep-rooted spring crop recover winter-deposited urine nitrogen?
}

\author{
G.M. LUCCI, M.A. SHEPHERD and W.T. CARLSON \\ AgResearch, Private Bag 3123, Hamilton, New Zealand
}

gina.lucci@agresearch.co.nz

\begin{abstract}
Grazing a winter forage crop can result in a substantial increase in soil nitrogen $(\mathrm{N})$ from urine deposition, with a significant proportion leached below $30 \mathrm{~cm}$ during winter. If a follow-on crop can be used to recover this soil $\mathrm{N}$ before the following drainage season, $\mathrm{N}$ leaching risk could be reduced. We tested if faster growing, or deeper-rooted, spring-sown crops would be more effective at recovering winter-deposited $\mathrm{N}$ than ryegrass based pasture. Urea-N ( $800 \mathrm{~kg} \mathrm{~N} / \mathrm{ha}$ ) was applied in June to simulate a dairy cow urine patch and was subsequently leached down the soil profile. In the spring, the plots were sown with ryegrass, chicory and clover, or barley and harvested manually. The following autumn, the amount of $\mathrm{N}$ in the $60-90 \mathrm{~cm}$ depth $(70$ $\mathrm{kg} \mathrm{N} / \mathrm{ha}$ ) was significantly less $(\mathrm{P}<0.05)$ under chicory and clover than under either barley $(104 \mathrm{~kg} \mathrm{~N} / \mathrm{ha})$ or ryegrass (107 kg N/ha), suggesting that chicory was able to access the deep $\mathrm{N}$ pool. These data, and earlier measurements, provide evidence that chicory is a viable strategy for $\mathrm{N}$ recovery after winter grazing.
\end{abstract}

Keywords: Nitrogen, urine, forage crop, leaching, chicory

\section{Introduction}

Nitrogen $(\mathrm{N})$ leaching losses from winter brassica crops grazed in early June can be large ( $>100 \mathrm{~kg} \mathrm{~N} / \mathrm{ha}$ ) (Shepherd et al. 2012). Nevertheless, there is potential for significant amounts of soil mineral $\mathrm{N}$ (nitrate- $\mathrm{N}$ and ammonia-N) to remain in the soil profile at the end of the drainage season. For example, Shepherd et al. (2012) measured 50-100 kg N/ha remaining in the soil to $90 \mathrm{~cm}$ depth at the end of drainage, with a large proportion $(>70 \%)$ of that below $30 \mathrm{~cm}$. It's uncertain if the follow-on crop would be able to reach and utilise that mineral $\mathrm{N}$ before the following drainage season. A clear relationship has been found between rooting depth and the depletion of soil $\mathrm{N}$ during the growing season (Thorup-Kristensen 2006).

Chicory has a tap-root and is capable of maintaining production even through dry conditions, especially in the first year (Li et al. 1997). Both these attributes make it a good candidate for accessing and utilising mineral $\mathrm{N}$ deep in the soil profile through the potentially dry summer months. Although it is not deep-rooted, barley has been found to have high growth rates over the summer (De Ruiter et al. 2009) and may also be able to establish and utilise mineral $\mathrm{N}$ more quickly than other crops.

In order to minimise the risk of further $\mathrm{N}$ leaching after a grazed forage crop, the question that needs to be addressed is: what are the best crops to recover deeply displaced $\mathrm{N}$ after grazing? We hypothesised that establishing a deep rooting crop, as opposed to ryegrass pasture, would recover more of this $\mathrm{N}$ and prevent it from being leached during the following winter. We report two experiments to test this; a preliminary study undertaken in summer 2010 and the main experiment in 2012.

\section{Methods}

Both experiments were located at a dairy farm runoff block near Mangakino, Central Plateau, on a freedraining pumice soil (Taupo sandy loam; Immature Orthic Pumice Soil; Shepherd et al. 2012.) This area receives, on average, $1350 \mathrm{~mm}$ rain/year (Data from NIWA station "Mangakino 2" number 12478; approximately $6 \mathrm{~km}$ from the trial site), mostly during the winter and spring months.

\section{Preliminary study}

A brassica crop (mixed swedes and kale) had been sown in spring 2009 for grazing by dry dairy cows in winter 2010. Approximately 0.5 ha was grazed on 22-24 June by dry dairy cows, and on 25 June plots were pegged out $(9 \times 12 \mathrm{~m} ; \mathrm{n}=34)$. In September, the chicory crop was sown, following conventional (disc/ tine) cultivation. Crop fertiliser was applied at sowing and no further fertiliser was applied to the trial area.

Soil mineral $\mathrm{N}$ was determined after the end of winter drainage, and again in the summer by sampling 18 of the plots (6 cores bulked on a plot basis) to $90 \mathrm{~cm}$ depth in $30 \mathrm{~cm}$ increments and analysed for mineral $\mathrm{N}$ by extraction of fresh soil with $2 \mathrm{M}$ potassium chloride.

\section{Main Experiment}

Two years later, in a different paddock on the same farm, another swede and kale mixed crop (50/50) was sown in November. However, rather than using cows to graze the winter crop, grazing was simulated to remove some of the variability associated with grazing and uneven urine distribution. Grazing was simulated on 13 June 2013 by pulling up the swedes and cutting off 
the kale $50 \mathrm{~mm}$ above ground level (a.g.l.) in an area large enough to accommodate all of the experiment treatments $\left(624 \mathrm{~m}^{2}\right)$. Then, urea- $\mathrm{N}(800 \mathrm{~kg} \mathrm{~N} / \mathrm{ha})$ was applied to simulate the $\mathrm{N}$ deposited in a urine patch (Selbie et al. 2015) covering the entire treatment area (i.e., one large patch), with the expectation that subsequent winter rain would move the applied $\mathrm{N}$ to depth in the soil profile. The trial area was split into six blocks with the three crop types randomly allotted to each plot within the block (i.e. randomised block design). Because of the different widths of the sowing equipment, the cereal plots were $4 \mathrm{~m} \times 10 \mathrm{~m}$, while the chicory/clover and pasture plots were $6 \mathrm{~m} \times 10 \mathrm{~m}$.

In September, the trial area was sprayed out with glyphosate $(1.8 \mathrm{~kg} / \mathrm{ha})$ to kill off any regrowth of weeds or brassicas. One month later (17 October 2013) the plots were sown with either pasture (control; shallow roots), chicory and clover mix (deep roots), or a forage cereal (fast growing, intermediate roots) to recover the urea N. Pasture was sown using a roller drill with $20 \mathrm{~kg} /$ ha 'Commando AR37' ryegrass, $3 \mathrm{~kg} / \mathrm{ha}$ 'Tribute' white clover, and $2 \mathrm{~kg} / \mathrm{ha}$ 'Mainstay' white clover. Chicory and clover mix (chicory/clover) was also sown using a roller drill and with $8 \mathrm{~kg} / \mathrm{ha}$ 'Choice' chicory, $3 \mathrm{~kg} /$ ha 'Tribute' white clover, and $3 \mathrm{~kg} / \mathrm{ha}$ 'Mainstay' white clover. Clover was sown together with the chicory and ryegrass, as is common practice, to supply the growing pasture with $\mathrm{N}$. This was not expected to affect the recovery of the displaced $\mathrm{N}$ below $30 \mathrm{~cm}$ depth. The triticale (variety 'Crackerjack') was sown with a roller drill $(180 \mathrm{~kg} / \mathrm{ha}$ seed). No nitrogen was applied to the crops, but at sowing all crops received $500 \mathrm{~kg} / \mathrm{ha}$ Serpentine Super $15 \mathrm{~K}$ fertiliser, based on soil testing of the site.

The triticale seedlings were extensively damaged by bird feeding, and on 2 November 2013 barley (variety 'Flora') was sown in its place ( $125 \mathrm{~kg} / \mathrm{ha})$. Some of the original triticale seedlings did survive, however, and the resulting crop was a mix of barley and triticale, hereafter referred to only as "barley".

\section{Harvests}

The pasture and chicory/clover was harvested on the same day when dry matter (DM) reached an average of approximately $2700 \mathrm{~kg} \mathrm{DM} / \mathrm{ha}$. This meant that during drier conditions, the yield of chicory/clover was greater than from the ryegrass pasture. Harvests of pasture and chicory/clover were made with a mower on an area of $42.8 \mathrm{~m}^{2}$ and cut to a residual of approximately 1700 $\mathrm{kg} \mathrm{DM} / \mathrm{ha}$. Samples were weighed on site, mixed, and a subsample was taken for $\% \mathrm{DM}$ and herbage $\% \mathrm{~N}$ analysis. At the final harvest, in addition to the crop $(>2.5 \mathrm{~cm}$ above ground level (a.g.1.)), the stubble (0-2.5 $\mathrm{cm}$ a.g.1.) was also collected to determine the total $\mathrm{N}$ content of the above-ground biomass. The barley was harvested at maturity (17 January 2013) and separated into crop (>10 cm a.g.1.) and stubble $(0-10 \mathrm{~cm}$ a.g.1.). Because of extreme drought during summer 2013, the planned crop of oats was not sown after the barley harvest, and only weeds grew until the end of the trial (2 May 2013). Weeds remaining in the barley plots were harvested, along with the pasture and chicory/ clover treatments on the final harvest day.

\section{Mineral N}

Soil mineral N was sampled in August and at the end of drainage in September to measure the displacement of applied urea-N. Mineral N was measured again when the barley was harvested (17 January 2013) and at the end of the experiment (2 May 2013) to look at changes in soil mineral $\mathrm{N}$ pools with depth $(0-15,15-30,30-$ $60,60-90 \mathrm{~cm}$ ). Five soil cores were taken per plot and bulked. Soil mineral $\mathrm{N}$ was measured on fresh soil samples using a $2 \mathrm{M}$ potassium chloride extraction.

\section{Statistical analysis}

Analysis of results of the preliminary study was done using a paired t-test in Genstat v. 12. Analysis of results of the main experiment was carried out using ANOVA in Genstat v. 15. The difference between treatments is reported using the least significant difference (LSD) at the $5 \%$ level of significance.

\section{Results}

\section{Preliminary study}

There was evidence that the deep mineral N $(60-90 \mathrm{~cm})$ decreased between the end of drainage in November and the sampling in February $(\mathrm{P}<0.001$; Table 1$)$, evidence that chicory may be effective at removing soil mineral $\mathrm{N}$ deep in the soil profile as there was no drainage in the intervening period (based on a water balance model; Woodward et al. 2001). The next step was to conduct a more detailed experiment.

\section{Main experiment}

The weather during the trial was characterised by average rainfall during the winter of 2012 with most of the rain falling in July, followed by lower than average rainfall in November to March resulting in an extreme summer drought (Figure 1). A drought was officially

Table 1 Soil mineral $\mathrm{N}(\mathrm{kg} \mathrm{N} / \mathrm{ha})$ measured under chicory in November (2010) and February (2011). Level of statistical significance is quoted for a paired t-test at each depth $(n=18)$.

\begin{tabular}{lcccc}
\hline Depth (cm) & $\mathbf{1 1 / 2 0 1 0}$ & $\mathbf{2 / 2 0 1 1}$ & Change & P value \\
\hline $0-30$ & 74 & 14 & -60 & $<0.001$ \\
$30-60$ & 22 & 6 & -16 & $<0.001$ \\
$60-90$ & 23 & 12 & -11 & $<0.001$ \\
\hline
\end{tabular}




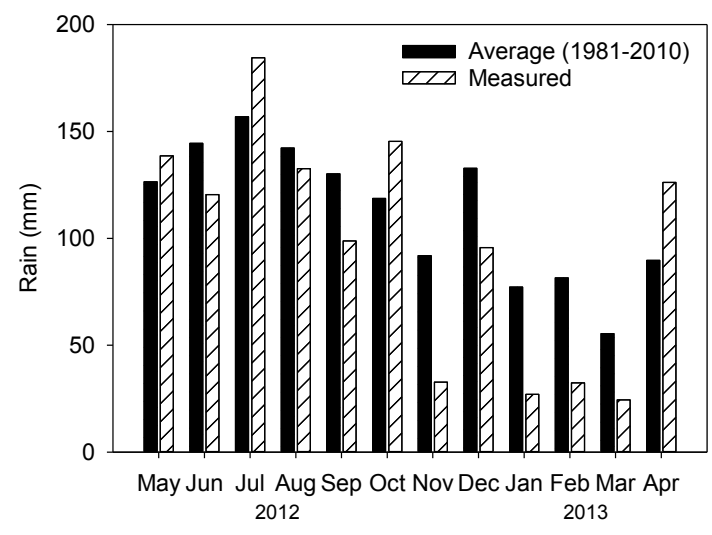

Figure 1 The 30-year average rainfall and the measured rainfall from May 2012 until April 2013 (Data from NIWA station \# 12478).

declared in this region on 6 March 2013. After the urea-N was applied in June 2012, approximately 400 $\mathrm{mm}$ of drainage (estimated using a water balance model; Woodward et al. 2001). occurred (ending late September). After the end of drainage in September 360 $\mathrm{kg} \mathrm{N} / \mathrm{ha}$ remained, with $50 \%$ below $30 \mathrm{~cm}$ depth.

\section{Harvests}

Between sowing in early November and the final harvest in May there were five harvests of pasture and chicory, one harvest of barley, and a subsequent harvest of the regrowth on the barley plots at the end of the experiment. During the period from November to May, the greatest amount of dry matter was harvested from the barley, followed by chicory/clover, and pasture (Table 2). Pasture growth was significantly greater than chicory/clover $(\mathrm{P}<0.05)$ during the first growth period until December. However, in subsequent harvests there was significantly more production from chicory than was achieved by the pasture during the summer months (February and March).

Barley had the highest rates of $\mathrm{N}$ uptake initially (Figure 2). However, after the barley was harvested, cumulative $\mathrm{N}$ uptake of the pasture and chicory caught up with, and then exceeded that of barley. Chicory/ clover took up the greatest amount of $\mathrm{N}(160 \mathrm{~kg} \mathrm{~N} / \mathrm{ha})$ from November to May.

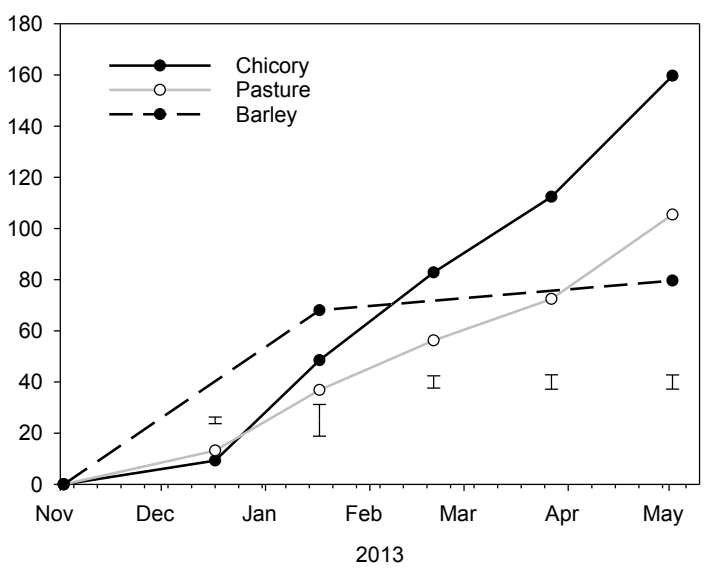

Figure 2 Cumulative $\mathrm{N}$ uptake in aboveground harvests. Bars represent the least significant difference (LSD $5 \%$ ) between crops for each harvest.

\section{Soil nitrogen}

Mineral $\mathrm{N}$ measured at the time of the barley harvest (January) showed no significant differences between crops, only between depths, with most of the mineral N (89-96\%) located below $30 \mathrm{~cm}$ depth (Figure 3). The final mineral $\mathrm{N}$ sampling in May showed a substantial decrease in the total amount of mineral $\mathrm{N}$ in the soil from $250 \mathrm{~kg} \mathrm{~N} / \mathrm{ha}$ to $130 \mathrm{~kg} \mathrm{~N} / \mathrm{ha}$ averaged across all crops. However, under the chicory/clover crop, the amount of mineral $\mathrm{N}$ in the $60-90 \mathrm{~cm}$ depth $(70 \mathrm{~kg} \mathrm{~N} /$ ha) was significantly less $(\mathrm{P}<0.05)$ than under barley or pasture (104-107 kg N/ha).

\section{Discussion}

The severe summer drought provided a harsh test for the chicory and pasture, with less than $50 \%$ of the average rainfall in November and January to March. Of the crops measured, barley took up the most $\mathrm{N}$ initially, but after harvest there was very limited potential for further uptake by volunteer weeds, because the bulk of the mineral $\mathrm{N}$ was below $30 \mathrm{~cm}$ (Figure 3). If the triticale had successfully established, it may have been possible to have a second harvest, with the established root system able to access $\mathrm{N}$ located deeper in the soil. It is possible that if another crop (oats) was sown following the barley that recovery of $\mathrm{N}$ in those plots

Table 2 Mean above ground yields in $\mathrm{kg} \mathrm{DM} / \mathrm{ha}$, with least significant differences (LSD) between treatments.

\begin{tabular}{lcccccc}
\hline & $\mathbf{1 7 / 1 2 / 2 0 1 2}$ & $\mathbf{1 7 / 1 / 2 0 1 3}$ & $\mathbf{2 0 / 2 / 2 0 1 3}$ & $\mathbf{2 7 / 3 / 2 0 1 3}$ & $\mathbf{2 / 5 / 2 0 1 3}$ & Total \\
\hline Barley & - & 6503 & - & - & $323^{1}$ & 6826 \\
Chicory & 264 & 1229 & 1133 & 854 & 1387 & 4869 \\
Pasture & 441 & 1068 & 703 & 479 & 942 & 3633 \\
\hline LSD (5\%) & 144 & 818 & 261 & 184 & 264 & 951 \\
\hline
\end{tabular}




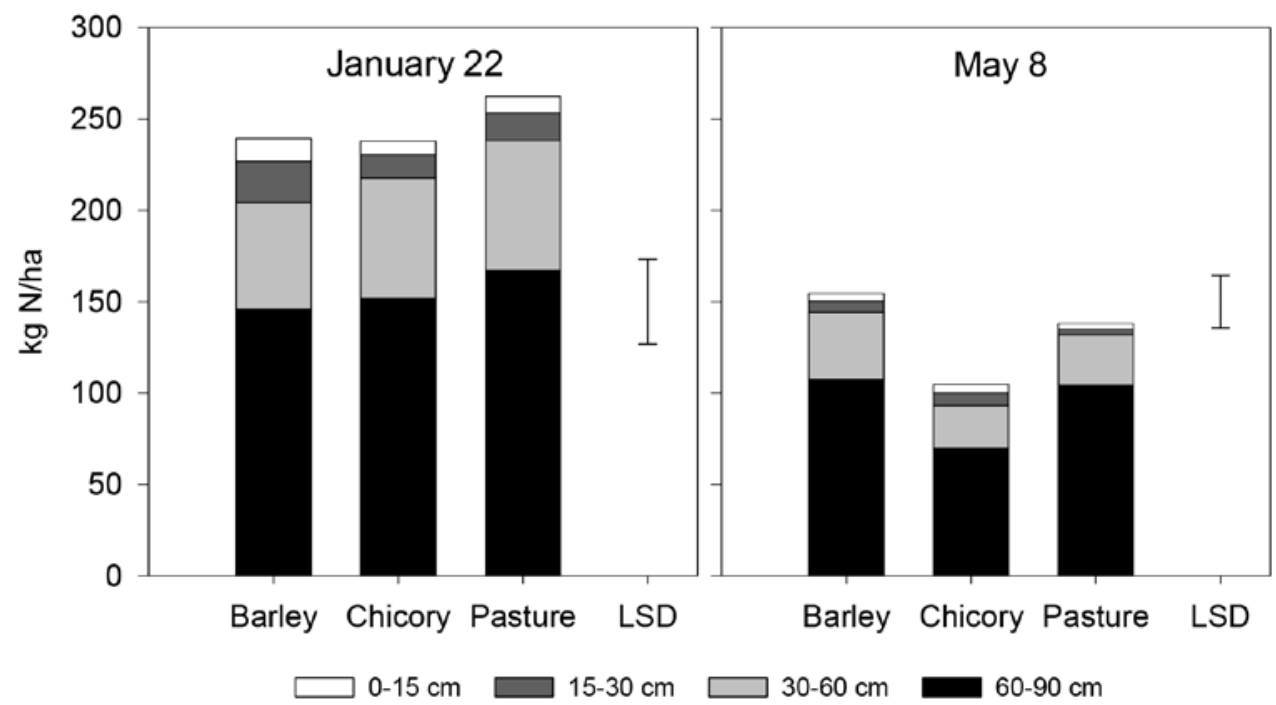

Figure 3 Mineral N measured at the barley harvest in January 2013 (left) and at the final harvest in May 2013 (right). Bar represents the least significant difference (LSD 5\%) between crop type and soil depth.

would have been greater, but the drought prevented this. However, the following crop of oats would mainly have had access to the $\mathrm{N}$ at shallow depths, while the bulk of the mineral $\mathrm{N}$ applied in June was found below $30 \mathrm{~cm}$.

Over the length of the trial, chicory recovered the greatest amount of $\mathrm{N}$ because of its superior growth during the drought, and slightly greater $\mathrm{N}$ concentration (data not shown). Nitrogen was recovered from depths greater than $60 \mathrm{~cm}$ that the other crops did not appear as effective at reaching (significant at $\mathrm{P}<0.05$ ). It is difficult to gauge how much of the $\mathrm{N}$ recovered by chicory/clover was fixed by clover, as no dissection of herbage was made to quantify clover contribution. Permanent clover/grass pastures fix an estimated 80 $100 \mathrm{~kg} \mathrm{~N} /$ ha/year (Ledgard 2001). The ryegrass pasture was also mixed with clover and therefore the effect would have been similar between swards.

The data from the main study corroborate chicory measurements made in the preliminary study, on the same property. Modelled drainage between measurements made in the main experiment between January and May were zero. This suggests that leaching was an unlikely pathway for the apparent disappearance of soil mineral $\mathrm{N}$, and that chicory was accessing this N. Combined, these data provide evidence that growing a deep rooting crop, such as chicory, is a viable strategy for recovering some of the $\mathrm{N}$ deposited during winter grazing. Chicory was also found to take up significantly more soil mineral $\mathrm{N}$ than ryegrass by Thorup-Kristensen (2006) with an additional $60 \mathrm{~kg} \mathrm{~N} / \mathrm{ha}$ remaining in the soil below ryegrass, down to $2 \mathrm{~m}$.

The problem of utilising the winter deposited urine is in getting the new crop established, and the time it takes for the roots to reach the depth where most of the $\mathrm{N}$ is located. Retaining more of the mineral $\mathrm{N}$ further up the profile (for example, with later grazing) will allow more of the mineral $\mathrm{N}$ to be accessed by spring-sown crops.

Another consideration is the fertiliser recommendations for crops following a winter forage crop. From the measurements made in the preliminary experiment, it appears that there is sufficient $\mathrm{N}$ in areas where urine- $\mathrm{N}$ has been deposited to grow a successful crop. If the stocking density during grazing of the winter crop were high, we hypothesise that a large proportion of the paddock would be covered in urine patches and additional $\mathrm{N}$ for the following crop may not be necessary early on. However, $\mathrm{N}$ fertiliser may still be required later in the season. This needs to be tested, as it may be another way of improving $\mathrm{N}$ use efficiency in these systems.

\section{ACKNOWLEDGEMENTS}

This experiment was undertaken as part of a Sustainable Farming Fund programme (SFF 11/010) which also included support from the following organisations: DairyNZ, Ballance Agri-Nutrients and Wairarapa Moana Incorporation (WMI).

\section{REFERENCES}

DeRuiter J.M.; Fletcher A.; Maley S.; Sim R.; George M. 2009. Aiming for $45 \mathrm{t} / \mathrm{ha}$ per annum: yield of supplementary feed crops grown in sequences designed for maximum productivity. Proceedings of the New Zealand Grassland Association 71: 107-116. 
Ledgard, S. 2001. Nitrogen cycling in low input legume-based agriculture, with emphasis on legume/ grass pastures. Plant and Soil 228: 43-59.

Li G.D.; Kemp P.D.; Hodgson J. 1997. Herbage production and persistence of Puna chicory (Cichorium intybus L.) under grazing management over 4 years. New Zealand Journal of Agricultural Research 40: 51-56.

Thorup-Kristensen, K. 2006. Effect of deep and shallow root systems on the dynamics of soil inorganic $\mathrm{N}$ during 3-year crop rotations. Plant and Soil 288: 233-248.
Selbie, D. R.; Buckthought, L. E. \& Shepherd, M. A. 2015. The challenge of the urine patch for managing nitrogen in grazed pasture systems. Advances in Agronomy 129: 229-292.

Shepherd, M.; Stafford, A. \& Smeaton, D. 2012. The use of a nitrification inhibitor $\left(\mathrm{DCn}^{\mathrm{TM}}\right)$ to reduce nitrate leaching under a winter-grazed forage crop in the Central Plateau. Proceedings of the New Zealand Grassland Association 74: 103-108.

Woodward, S.J R.; Barker, D.J.; Zyskowski, R.F. 2001.A practical model for predicting soil water deficit in New Zealand pastures. New Zealand Journal of Agricultural Research 44: 91-109. 
